\title{
The 120th Anniversary of the Birth of Kastuś Kalinoŭski in the BSSR (1958)
}

\author{
BY \\ ANDRUŚ UNUČAK*
}

In 1958, 120 years had passed since the birth of Kastuś Kalinoŭski on 2 February 1838. The anniversaries of Kalinoŭski's birth had been regularly commemorated in the BSSR since 1924, the year that marked the 60th anniversary of his death. Commemoration of anniversaries was an important factor in the formation of the image of Kalinoŭski; they served to popularize him, and also to stimulate further research into his life and activities. The main feature of Kalinoŭski's anniversaries in the BSSR was that if they were not celebrated widely, then at least they were marked in such a way as to be visible at the state level. Scholars, writers, painters, sculptors, and other intellectuals working in state institutions were all involved in the process.

1958 was the time of Khrushchev's 'thaw' in the Soviet Union; the BSSR was affected as well. It was a time when the Belarusian intelligentsia received tacit permission to 'rehabilitate' and research the life and work of many people and events of national history and culture. The anniversaries became occasions to talk about figures of Belarusian history, to commemorate them and to broaden knowledge of them in society. It was all directly connected to the celebration of the 120 th anniversary of the birth of one of the leaders of the Uprising of 1863 in Belarus.

I will try to answer the question of how this anniversary influenced the formation of Kalinoŭski's image in official discourse in the BSSR.

First, it should be noted that many researchers of the period have the intuitive idea that Soviet ideology was something monolithic, finalized in the 1930s - early 1950 s, and before the end of the 1980s only had some cosmetic changes.

This paper intends to show that there was an intellectual process in the BSSR, and that Kalinoŭski's personality was a 'memory spot' where one could talk about the Belarusian nation, national consciousness and statehood. But in order to remember Kalinoŭski, permission or, at least, the absence of the ban was not enough. There was a need for a reason to do it, such as an anniversary.

* Andruś Unučak - PhD in History, Head of the Department of Belarusian Statehood of the Institute of History, National Academy of Sciences of Belarus (Minsk). 
In 1957 at the Plenum of the Writers' Union of the BSSR it was announced that theatres were planning to stage the play Kastuś Kalinoŭski by Jeǔścihniej Mirovič to mark the 40th anniversary of the Great October Revolution (BDAMLiM F.78 Ark. 221). Staging Jeǔścihniej Mirovič’s play to commemorate the anniversary of the October Revolution ideologically opened the way for the celebration of Kalinoŭski's anniversary in 1958. A programme of events commemorating Kalinoŭski was supported at the level of the Secretary of the Central Committee of the Communist Party of Belarus, Cimafiej Harbunoŭ, who signed the recommendation for the Hrodna Regional Party Committee to use the proposals outlined by the writer Aliaksiej Karpiuk back on 9 January 1956.

In this letter, among other things, Aliaksiej Karpiuk wrote:

Until now, in Hrodna region we have not commemorated prominent figures of Belarusian culture: Kalinoŭski, Elaiza Paškievič (Ciotka), Bahdanovič, Karski, and others. It is not surprising, but still, even such an outstanding national hero as Kalinoŭski, well known all over the USSR, in his native Śvislač does not even have a memorial plaque $[. .$.$] Among the local non-party intellectuals these facts$ cause various rumours and twisted conversations about the alleged disregard for Belarusian culture, which I, as a communist, consider it my duty to draw your attention to.

To put an end to those rumours, and to express tribute to the outstanding people of our nation, in my opinion, we must first do the following: On Kalinoŭski: 1. To name the Hrodna Pedagogical Institute after Kalinoŭski (by 16 February, when Kalinoŭski was executed $^{1}$ ); 2. To name Śvislač high school after Kalinoŭski; 3. To install a plaque on the site of the former school, where Kalinoŭski studied; 4. To name the central street in Śvislač after Kalinoŭski (Spadčyna 2010).

The writer claimed that he voiced proposals that would not require large material costs. The second step would be the installation of a monument to Kalinoŭski, and a separate committee would be created for this step.

Exactly one year later on 15 January 1957, the Central Committee of the Communist Party of Belarus sent a letter signed by Cimafiej Harbunoŭ to the Secretary of the Hrodna Regional Committee Baranaŭ. It read:

I am sending you a request from the deputy of the Hrodna Regional Association comrade Karpiuk to commemorate the outstanding 
figures of Belarusian culture: Kalinoŭski, Elaiza Paškievič (Ciotka), Bahdanovič, and Karski. I think that the writer's proposal deserves attention. Comrade Karpiuk's proposal is supported by the Board of the Writers Union of the Belarusian Soviet Socialist Republic.

For my part, I think that this event should take place, and that there is a lot of meaning in it. We could name the Hrodna Pedagogical Institute after Kalinoŭski; install a plaque on the site of the former school, where Kalinoŭski studied; name one of the streets in Śvislač after Kalinoŭski (Spadčyna 2010).

As is evident, at the level of the Central Committee almost all Karpiuk's proposals were supported, except for the monument. Their implementation was obviously timed to coincide with the 120th anniversary of the birth of the head of the Uprising.

In January 1958, the Hrodna Regional Committee of the Communist Party of Belarus and the Hrodna Regional Executive Committee decided to found a Kalinoŭski museum in Śvislač. Information about this appeared in the Literature and Art newspaper, a body of the Union of Writers of the BSSR (Kisialioŭ 1966, 217).

The central article to commemorate the 120th anniversary of Kalinoŭski was written by professor of the Belarusian State University, philosopher Ivan Luščycki (1958 (1), 2). Originally, his article was titled Kalinoŭski’s Views on the National issue (the 120th Anniversary of his Birth) (BDAMLiM F.12 Ark. 52-71). It was momentous that for the anniversary article Ivan Luščycki chose one of the most critical issues related to Kalinoŭski - the national question. However, at the same time, the author noted that the main issue of the 1863-1864 Uprising was an 'agrarian-peasant issue.'

Despite the fact that the title of the article was changed, it was in fact almost exclusively devoted to the national views of Kalinoŭski. I. Luščycki wrote, Since the issue of the revolutionary democratic views of Kalinoŭski has been more or less described, we will deliberately dwell on his views on the national question (Luščycki $1958(1), 2)$.

First, the author mentioned biographical facts about Kalinoŭski which became the starting point for further descriptions of his personality and activities. Professor of Belarusian State University wrote,

The outstanding Belarusian revolutionary democrat Kanstancin Kalinoŭski was born on 21 January 1838 in the Mastaŭliany estate, Hrodna district. He came from a Belarusian gentry family. 
After that, the article was changed by editorial notes. Thus, the following paragraph has been deleted:

The value of Kalinoŭski's publicist and oral propaganda activities is that he spoke to the people in his native Belarusian language. [...] It is known that the Great Russian and Polish nationalists had a scornful attitude towards the Belarusian language. They called it a 'peasant', 'homespun' language. In contrast to the nationalists of various kinds, Kalinoŭski advocates the right of the Belarusian people to develop their national culture, language and literature (BDAMLiM F.12 Ark.54).

However, despite this editorial note, later in the text there was information that:

Kalinoŭski fought for the establishment of schools with instruction in native language [...] exposed the tsarist government that pushed a policy of forced Russification of schools and appointed chauvinistic officials as teachers [...] He demanded that in schools children be taught in their native language or the language in which people wish to teach their own children (underlined by author - AU) (Luščycki $1958(1), 2)$.

The latter demand was clearly included due to the fact that the number of Russian-language schools in the BSSR had steadily increased.

According to Ivan Luščycki, 'the Polish bourgeois-landlord nationalists' and 'the Great Russian landlord chauvinists' did their best to 'distort' Kalinoŭski's views on the national question:

With this aim they invented and published untrue facts. The Polish bourgeois-landlord nationalists spoke about Kalinoŭski and his supporters being 'separatists'. As if he wanted to break any connections with the Polish national liberation movement and to act independently from the Polish Provisional Government, to struggle against tsarism and the landlords for the formation of an independent Lithuanian-Belarusian state. On the other hand, the Great Russian landlord chauvinists spread rumours that Kalinoŭski was a Polish revolutionary who fought for the national liberation of Poland, for the separation of Belarus and Lithuania from Russia and for the formation of an independent Lithuanian-Belarusian state as a part of the Polish federation (Luščycki 1958 (1), 2).

After criticizing the Russians and the Polish, the author focused on the views of 'the Belarusian nationalists': 
It is not surprising that the enemies of workers - Belarusian bourgeois nationalists - were so troubled by such fabrications (about Kalinoŭski's national views - A.U.). With all their beings they hated all progressive, all Russian, as well as Belarusian, they were trying in every way to forge Kalinoŭski's ideological legacy, pointing to him as a fighter against Russia. They willingly, together with the Great Russian landlord chauvinists, ascribed to Kalinoŭski a demand for an independent Belarusian-Lithuanian state in isolation from Russia (Luščycki 1958 (1), 2).

Interestingly, the editors deleted Ivan Luščycki’s paragraph, which refers to Kalinoŭski's connection with the BNR. This paragraph came immediately after criticism of 'Belarusian bourgeois nationalists':

falsifying history, they ('Belarusian bourgeois nationalists' - A.U.) lied through their teeth, told lies about Kalinoŭski and the people of Belarus, claiming that Kalinoŭski's idea of the independence of Belarus from Russia was realized on 25 March 1918 by the Act on creating a puppet 'Belarusian Democratic Republic', which was headed by the enemies of the working masses - Belarusian bourgeois nationalists, who intended to sell someone else's motherland wholesale and retail (BDAMLiM F.12 Ark.60).

The editor deleted from the anniversary article Ivan Luščycki's criticism of conclusions by Polish researcher Wiktor Kardowicz, who wrote that Kalinoŭski saw the future of Belarus in a federal state with Poland (BDAMLiM F.12 Ark.57).

Interestingly, Ivan Luščycki criticized not only the ideological enemies of the Soviet system, but also the authors of a textbook on the history published in 1954 in Moscow. He wrote that:

the authors of the History of the USSR textbook edited by prof. M.V. Nechkina ascribe the requirement to establish the LithuanianBelarusian republic to Belarusian revolutionary democrats. They continue to adhere to this point of view not only in the first edition, but also in the second, revised and enlarged edition of the textbook. 'The movement in Belarus', it says, - 'was headed by the 'Red rzad' (red government), which aimed mainly to strength ties with the masses'.

The 'Red rzad' acted under the leadership of the Belarusian revolutionary Kalinoŭski, who learned from Russian revolutionary democrats and was an outstanding revolutionary democrat himself. The rzad demanded a radical solution to the peasant issue, the division 
of estates among the peasants and the establishment of a separate Lithuanian-Belarusian republic (underlined by I. Luščycki - A.U.) (Istoria SSSR 1954, 447).

Furthermore,

The authors of the textbook in general give a correct assessment of Kalinoŭski's activities, but they repeated the invented story that Kalinoŭski and his supporters fought for a separate LithuanianBelarusian state. The authors did not critically study the meaning of this issue at that time (BDAMLiM F.12 Ark. 61-62).

According to Ivan Luščycki and the editors of Literature and Art:

the creation of an independent Lithuanian-Belarusian state was a reactionary slogan then, since it would mean the creation of a State apart from Russia. And to tear Belarus and Lithuania apart from Russia would mean to give those lands directly to the Polish landlords (BDAMLiM F.12 Ark. 62).

According to Ivan Luščycki, Kalinoŭski was a supporter of the 'federalist theory' of Alexander Herzen, who

linked the issue of the self-determination of Lithuania, Belarus and Ukraine with the question of overthrowing the tsarist autocracy. Prior to that, he recommended leaving the question of self-determination open (Luščycki 1958 (1), 2).

The manuscript of the anniversary article also contained a paragraph, later deleted by editors, in which the author noted that Kalinoŭski acknowledged the strong ties between Belarus and Poland:

Kalinoŭski recognizes that the fact that Lithuania and Belarus were under the rule of the landlords in Poland for more than two centuries left its mark. 'The network, which covers all classes', wrote Kalinoŭski 'is based on so many traditions and even prejudices that to unravel it, to destroy and to create something new would require a century of systematic mental work.' At the same time, Kalinoŭski draws attention to the fact that the Russian policy of colonization of the border regions unwittingly reinforces the sympathy of Belarus and Lithuania to Poland (BDAMLiM F.12 Ark. 68).

In the same issue of Literature and Art, editors published another anniversary article by writer Ilia Klaz (Klaz 1958, 2-3). According to the author, Kalinoŭski's school in Śvislač was 'destroyed by the fascist invaders.' Klaz also noted that 'the key factor in shaping Kalinoŭski's political views was his friendship with 
Sigismund Sierakowski, a friend of Shevchenko and Chernyshevsky' (Klaz 1958, 2-3). Another peculiarity of Klaz's article was the claim that he had found a relative of Kalinoŭski through parental lineage, who 'turned out to be Franc Kalinoŭski, a 76-year-old farmer from Navozy village, Paryčy' (Klaz 1958, 3). This man was the grandson of Kalinoŭski's father's brother, Symon Kalinoŭski. According to the author, the family of this man preserved the memory of Kalinoŭski.

An article by Jermalovič, a future famous historian, was published for the anniversary in Maladziečna's regional newspaper The Red Flag (Jermalovič 1958, 4). It showed a similarity with I. Luščycki's article in the clear division between the 'Polish uprising' and the 'Belarus-Lithuanian peasant revolt':

[...] the consistent democratic position [of Kalinoŭski] in the leadership of the revolt has caused discontent and hostility from the leaders of the Polish uprising, which also took place in this time [...] It is clear why the tsarist government was more concerned about the Belarusian-Lithuanian than the Polish uprising (Jermalovič 1958, 4).

The author called Kalinoŭski 'a great national hero.' Recalling the definition of Aliaksej Karpiuk in a letter to Cimafiej Harbunoŭ, it can be stated that treating Kalinoŭski as a 'national hero' gradually entered into the discourse of the Belarusian national intelligentsia.

In the first issue of Polymia in 1958 there was an article by Smirnov, a historian from Moscow. The article was devoted to reflecting on Kalinoŭski's image in Polish historiography (Smirnoŭ 1958, 170-178). The author also called Kalinoŭski a 'national hero of Belarus'(Smirnoŭ 1958, 172).

Most of Smirnov's article was devoted to criticizing the afore-mentioned monograph by Kardowicz. He did not agree with the researcher's thesis about the 'Polish origin' of Kalinoŭski and noted that the Kalinoŭski family at least since 1679 had lived in Hrodna. The author, who was from Moscow, also disliked Kardowicz's high opinion of Polish social thought and culture, which were considered the ideological basis of Kalinoŭski's revolutionary democracy:

W. Kardowicz one-sidedly shows the development of revolutionary democracy in Belarus and the formation of Kalinoŭski's worldview, highlighting the influence of Polish culture. The author ignores the significance of Russian revolutionary democracy in the development of liberation movements in Belarus and Lithuania [...] having announced that Kalinoŭski was a Pole, the author considers it unnecessary to talk about the impact of the Russian revolutionaries on the revolutionary circles of Belarus (Smirnoŭ 1958, 173-174). 
Smirnov argued that during the uprising Kalinoŭski fought against the uprising centre in Warsaw. He also denied Kalinoŭski's authorship of Letter to the Peasants of the Polish Land, because its known copies bore a stamp of the Warsaw National Government and not of the Revolutionary Committee in Viĺnia (Smirnoŭ 1958, 178).

Also in 1958, a monograph was published by Ivan Luščycki called 'Essays on the History of Socio-political and Philosophical Thought in Belarus', in which the author elaborated on Kalinoŭski's views (Luščycki 1958 (2), 229-242). Conclusions and postulates of anniversary article were included in this monograph.

In 1958, Adolff Huhieĺ and Raisa Kudrevič completed their collaborative painting titled Kastuś Kalinoŭski. This painting is now exhibited at the National Art Museum of Belarus. To a certain extent, it is a 'socialist realism' benchmark reflecting Kalinoŭski in the BSSR. One can clearly simultaneously trace 'Russian', 'Soviet' and 'Belarusian' connotations in this picture (Luščycki 1958 (2), 41). Russian connotations

are expressed by Kalinoŭski's clothing - a shirt with a belt, a black tie (associated with 'narodniki'). It is a Russian and at the same time Soviet connotation [...] The posture explicitly refers to Soviet connotations. This is a variation of one of the postures adopted in Soviet iconography for images of Lenin, where he stands in front of workers and peasants [...] Finally, the Belarusian connotations are related to a sack of potatoes in the corner of the picture (Luščycki 1958 (2), 41-42).

In November 1958 a monument to Kalinoŭski was unveiled in Śvislač (sculptor - Zair Azgur) (Kisialioŭ 1966, 219). The Literature and Art newspaper reported that:

A few days ago in the city park of Śvislač 's district center a monument to the well-known Belarusian revolutionary democrat, leader of the peasant uprising of 1863 Kanstancin Kalinoŭski was inaugurated. The residents of Śvislač and farmers from nearby villages gathered in the park. A ceremonial meeting was opened by Deputy Chairman of the City Council of Workers' Deputies, comrade Klaŭsuc. Then speeches were delivered by the director of the school named after Kalinoŭski, comrade Kuciapalaŭ, chairman of the September 17 kolkhoz comrade Poŭzikaŭ, and high school student, Tamara Suchockaja. They said that Śvislač residents remember their fellow countryman. The veil fell down, the gathered people could see Kalinoŭski's bust on a high pedestal (Pomnik K. Kalinoŭskamu 1958, 2). 
Let us draw some conclusions. Firstly, the 120th anniversary of Kalinoŭski's birth in 1958 was celebrated on a considerable scale in the BSSR. The initiative came from the Belarusian intelligentsia, and it received some support from the party leadership. Secondly, the anniversary events and publications emphasized the national element in 'Kalinoŭski's program'. The ideological line of the Belarusian Communist Party was that 'Kalinoŭski supported a federation with Russia'.

At the same time, criticism of the opinion that Kalinoŭski stood 'for the independence of a Belarusian-Lithuanian state' allowed promotion of the image of Kalinoŭski as a supporter of the Belarusian idea among those who knew how to read between the lines. Thirdly, two tendencies could be observed during the celebration: on the one hand, the Belarusian intelligentsia wanted to strengthen Belarusian national consciousness, and, on the other, the Soviet nomenclature attempted to use Kalinoŭski's name to reinforce the legitimacy of their power and the Soviet identity of Belarusians. It should also be noted that the debate on the view of the Polish researcher Kardowicz in the BSSR contributed to further 'Belarusization' of Kalinoŭski.

\section{References}

BDAMLiM (Bielaruski dziaržaŭny archiŭ-muzej litaratury i mastactva). F.12, vop.1, adz. z. 360, Ark. 52-71.

BDAMLiM (Bielaruski dziaržaŭny archiŭ-muzej litaratury i mastactva). F.12, vop.1, adz. z. 360, Ark. 54.

BDAMLiM (Bielaruski dziaržaŭny archiŭ-muzej litaratury i mastactva). F.12, vop.1, adz. z. 360, Ark. 57.

BDAMLiM (Bielaruski dziaržaŭny archiŭ-muzej litaratury i mastactva). F.12, vop.1, adz. z. 360, Ark. 60.

BDAMLiM (Bielaruski dziaržaŭny archiŭ-muzej litaratury i mastactva). F.12, vop.1, adz. z. 360, Ark. 62.

BDAMLiM (Bielaruski dziaržaŭny archiŭ-muzej litaratury i mastactva). F.12, vop.1, adz. z. 360, Ark. 68.

BDAMLiM (Bielaruski dziaržaŭny archiŭ-muzej litaratury i mastactva). F.78, vop.1, adz. z. 76, Ark. 221.

Ćvikievič, Ivan, 1924. Kastuś Kalinoŭski. Biohrafična-histaryčny narys (K 60-ci hoddziu jaho smierci), Polymia, 2. 
Istoria SSSR, 1954. vol. 2. Rossia v 19 viekie. Krizis feodalizma. Utverždenie kapitalizma. Pod redakciei chlena-korrespondent Akademii nauk SSSR M.V. Nechkinoi, Moscow: Gosudarstvennoie izdatel'stvo politicheskoi literatury.

Jermalovič, Mikola, 1958. 'Kastuś Kalinoŭski (Da 120-hoddzia z dnia naradžennia)', Čyrvony sciah, 24, 2 February.

Kisialioŭ, Hienadź, 1966. Z dumaj pra Bielaruś, Minsk: Bielaruś.

Klaz, Illia, 1958. 'Zmagar za ščascie naroda', Litaratura i mastactva, 7, 22 January.

Luščycki, Ivan, 1958 (1). 'Vydatny revaliucyjanier-demakrat (Da 120-hoddzia z dnia naradžennia K. Kalinoŭskaha)', Litaratura i mastactva, 7, 22 January.

—, 1958 (2). Narysy pa historyi hramadska-palitychnaj i filasofskaj dumki $\breve{u}$ Bielarusi $\breve{u}$ druhoj palavine 19 vieku, Minsk: Vydaviectva Bielaruskaha dziaržaŭnaha ŭniviersiteta.

'Pomnik K. Kalinoŭskamu', 1958. Litaratura i mastactva, 91, 15 November.

Smirnoŭ, Anatoĺ, 1958. 'Historyki narodnaj Polščy pra Kastusia Kalinoŭskaha', Polymia, 1.

Spadčyna akademika Jaŭchima Karskaha. Da 150-hoddzia z dnia naradžennia [Electronic resource. CD-ROM], Minsk, 2010.

Zimionka, Anatoĺ, 1924. 'Zachodniamu bratu. Pamiaci K. Kalinoŭskaha', Polymia, 2. 